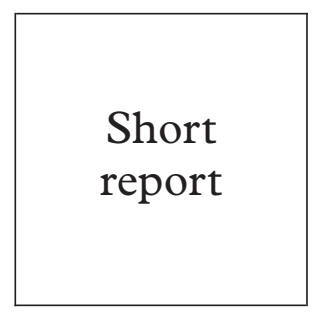

Department of Microbiology, The University of the West Indies, Kingston 7, Jamaica M Smikle G Dowe

Comprehensive Health Centre, Ministry of Health, Kingston, Jamaica

T Hylton-Kong

Immunology Unit, Ministry of Health, Kingston, Jamaica E Williams

Correspondence to: Monica Smikle, PhD, Department of Microbiology, The University of the West Indies, Mona, Kingston 7, Jamaica, West Indies msmikle@uwimona.edu.jm

Accepted for publication 3 April 2001

\title{
Hepatitis B and C viruses and sexually transmitted disease patients in Jamaica
}

\author{
M Smikle, G Dowe, T Hylton-Kong, E Williams
}

Objectives: To determine the prevalence of hepatitis C virus (HCV), hepatitis B virus (HBV), human immunodeficiency virus (HIV) infections, and risk factors for HCV and HBV infections in sexually transmitted disease (STD) clinics in Jamaica.

Methods: A prospective observational cohort study was carried out. Blood was collected from 485 consecutive patients attending the comprehensive health centre in Kingston, Jamaica. Serum was tested using commercially prepared reagents and standard procedures for antibodies to HCV (anti-HCV), hepatitis B core antigen (anti-HBc), hepatitis B surface antigen (HBsAg), HIV-1 infection, and syphilitic infection. Sociodemographic and sexual characteristics of the patients were recorded for assessment as risk factors for HCV and HBV infections.

Results: None of the patients had anti-HCV, $21.0 \%$ had anti-HBc, 3.2\% HBsAg, $2.5 \%$ tested positive for HIV-1, and $5.2 \%$ had reactive serological test for syphilis. Age was the only independent risk factor identified for anti-HBc positivity.

Conclusions: The data obtained in this study were not in support of sexual transmission of HCV or HBV infections in Jamaica. Carefully designed multicentre studies could provide more consistent information on the transmission of these viruses by sexual routes.

(Sex Transm Inf 2001;77:295-296)

Keywords: prevalence; hepatitis B; hepatitis C

\section{Introduction}

The modes of transmission of hepatitis $C$ virus (HCV) have not been completely identified and differ between countries. ${ }^{1-3}$ In countries where antibody screening is done most new infections of $\mathrm{HCV}$ and hepatitis B virus (HBV) are related to injecting drug use. ${ }^{13}$ Whereas HBV has been shown to be mostly sexually transmitted, in some countries, the role of sexual behaviour in the transmission of $\mathrm{HCV}$ is controversial. ${ }^{1-6}$

We report a study of $\mathrm{HCV}$ and $\mathrm{HBV}$ infections in a sexually transmitted disease (STD) clinic population in Jamaica where donor blood is screened for $\mathrm{HBV}$ but not $\mathrm{HCV}$.

\section{Patients and methods}

During 1998-9, after ethical approval and informed consent were obtained, a structured questionnaire was administered to 485 (197 males, 288 females; mean age 28 years; range 15-75 years) consecutive patients presenting at the comprehensive health centre, the STD clinic in Kingston. The questionnaire pertained to sociodemographic characteristics; medical history; sexual practices and behaviours; and history of illicit drug use by the patients and their sexual partners. Blood samples $(10 \mathrm{ml})$, collected from each participant, were tested for syphilitic infection using the venereal disease research laboratory test and reactive results confirmed by the fluorescent treponemal antibody absorption test; antibodies to HCV (anti-HCV); HIV-1; hepatitis B core antigen (anti-HBc) and hepatitis B surface antigen (HBsAg) by EIA (Abbott Diagnostics, Abbott Park, IL, USA). Anti-HCV and antiHIV-1 positivity were confirmed by western
Table 1 Characteristics of 485 anti-HCV negative patients presenting at a sexually transmitted disease (STD) clinic in Famaica

\begin{tabular}{|c|c|}
\hline Characteristic & $\begin{array}{l}\text { Frequency } \\
(\%)\end{array}$ \\
\hline \multicolumn{2}{|l|}{ Sex } \\
\hline Males & $197(40.6)$ \\
\hline Females & $288(59.4)$ \\
\hline \multicolumn{2}{|l|}{ Age } \\
\hline Younger than 24 years & $212(43.7)$ \\
\hline Older than 24 years & $273(56.3)$ \\
\hline \multicolumn{2}{|l|}{ Sexual practices } \\
\hline Genital sex & $485(100)$ \\
\hline Anogenital sex & $6(1.2)$ \\
\hline Men having sex with men & $0(0.0)$ \\
\hline Never used condoms & $173(35.6)$ \\
\hline Always used condoms & $23(4.7)$ \\
\hline \multicolumn{2}{|l|}{ STD status } \\
\hline First STD visit & $242(49.9)$ \\
\hline Repeat STD visit & $243(50.1)$ \\
\hline Anti-HBc & $102(21.0)$ \\
\hline HBsAg & $16(3.2)$ \\
\hline HIV positive & $12(2.5)$ \\
\hline Syphilis serology reactive & $25(5.1)$ \\
\hline Previous history of STD & $371(76.4)$ \\
\hline Previous history of syphilis & $38(10.5)$ \\
\hline Previous history of gonorrhea & $259(53.4)$ \\
\hline Previous history of blood transfusion & $6(1.2)$ \\
\hline$\leqslant 2$ new sexual partners in previous 12 months & $274(56.4)$ \\
\hline$>$ new sexual partner in previous 12 months & $211(43.5)$ \\
\hline Commercial sex worker & $0(0.0)$ \\
\hline \multicolumn{2}{|l|}{ Drug history } \\
\hline Use cocaine & $3(0.6)$ \\
\hline Use marijuana & $143(29.4)$ \\
\hline Use injecting drug & $0(0.0)$ \\
\hline \multicolumn{2}{|l|}{ Partners drug history } \\
\hline Use cocaine & $2(0.4)$ \\
\hline Use marijuana & $146(30.4)$ \\
\hline Use injecting drug & $2(0.4)$ \\
\hline
\end{tabular}

* The mean age at first sexual experience was 14.8 years. $\mathrm{STD}=$ sexually transmitted disease; anti-HBc $=$ anti-hepatitis $\mathrm{B}$ core; HBsAg = hepatitis $\mathrm{B}$ surface antigen; HIV = human immunodeficiency virus.

blot (Murex Diagnostics, Columbia). The SPSS- 8 statistical package was used to analyse the data. 


\section{Results}

None of the patients tested positive for anti-HCV. Anti-HBc antibodies were found in $21.0 \%$ and $\mathrm{HBsAg}$ in $3.2 \% ; 5.2 \%$ were syphilitic and $2.5 \%$ tested positive for HIV-1. The characteristics of the patients are shown in table 1. Anti-HBc positivity correlated with increasing age $(11.3 \%$ in those under 24 years $v$ $22.0 \%$ in those over 24 years; $\chi^{2}=9.5$; $\mathrm{p}<0.002)$, repeat STD clinic visits $(13.0 \% v$ $\left.22.0 \% ; \chi^{2}=5.7 ; \mathrm{p}<0.02\right)$, and condom use $\left(19.2 \%\right.$ v $14.7 \%$ v $34.8 \% ; \chi^{2}=6.67 ; \mathrm{p}<0.036$ for those who never used condoms, used condoms some of the times or always used condoms, respectively). Multivariate regression analyses identified age as the only independent risk factor for anti-HBc positivity (adjusted odds ratio $0.45 ; 95 \%$ confidence interval, $0.2715-0.7565)$.

\section{Discussion}

Anti-HCV positivity in this large group of STD clinic patients was rare. Similar prevalences $(0-0.5 \%)$ were reported in pregnant women and blood donors in Jamaica. ${ }^{4}$ The prevalence of anti-HBc resembled that observed in low risk groups, but was lower than that reported in commercial sex workers. ${ }^{4}$ Our results may be explained partially by the low prevalence of history of blood transfusion, injection drug and crack/cocaine use. Black race has been cited as a risk factor for $\mathrm{HCV}$ infection making the absence of anti-HCV in Jamaican STD patients more striking. ${ }^{6}$

The results were not consistent with transmission of HCV or HBV in Jamaica by sexual routes. The risk of sexual transmission of $\mathrm{HCV}$ and HBV seem to vary with the population studied.

1 Recommendations for prevention and control of hepatitis C virus $(\mathrm{HCV})$ infection and $\mathrm{HCV}$-related chronic diseases. MMWR 1998:47.

2 Weinstock HS, Bolan G, Reingold AL, et al. Hepatitis C virus infection among patients attending a clinic for sexually transmitted disease. FAMA 1993;269:392-4.

3 World Health Organization. Global surveillance and control of hepatitis C. F Viral Hep 1999;6:35-47.

4 King SD, Dodd RY, Haynes G, et al. Prevalence of antibodies to hepatitis $\mathrm{C}$ virus and other markers in Jamaica. West Ind Med $\mathcal{F} 1995 ; 44: 55-7$.

5 Santana Rodriquez OE, Male Gil ML, Hernandez Santana JF, et al. Prevalence of serologic markers of HBV, HDV, $\mathrm{HCV}$ and HIV in non-injection drug users compared to injection drug users in Gran Camaria Spain. Eur $f$ Epidemiol 1998;14:555-61.

6 Thomas DL, Cannon RO, Shapiro CN, et al. Hepatitis C, hepatitis $\mathrm{B}$ and human immunodeficiency virus infections among non-intravenous drug using patients attending clinics for sexually transmitted diseases. F Infect Dis 1994;169: 990-5. 